\title{
Influences of Dietary Lipid Source on the Growth and Fatty Acid Composition of Juvenile Sea Cucumber Apostichopus japonicus
}

\author{
Joo-Young Seo ${ }^{1}$, Jin Choi ${ }^{2}$ and Sang-Min Lee ${ }^{1 *}$ \\ ${ }^{1}$ Faculty of Marine Bioscience and Technology, Gangneung-Wonju National University, \\ Gangneung 210-702, Korea \\ ${ }^{2}$ Marine Biology Center for Research \& Education, Gangneung-Wonju National University, \\ Gangneung 210-853, Korea
}

\begin{abstract}
A study was conducted to investigate the effects of dietary lipid sources on the growth and fatty acid composition of juvenile sea cucumber. For 12 weeks, three replicate groups of sea cucumber (average weight $1.4 \mathrm{~g}$ ) were fed one of three diets, containing squid liver oil (SLO), soybean oil (SO), or linseed oil (LO) as a dietary lipid source, or a control diet (CON) without added lipids. Sea cucumber survival was not significantly different among dietary treatments $(P>0.05)$. The highest weight gain was observed in sea cucumber fed the SLO diet, whereas the weight gain of sea cucumber fed the SO diet was the lowest among dietary treatments $(P<0.05)$. No significant differences were found in the moisture, crude protein, crude lipid, and ash contents of whole sea cucumber body among dietary treatments $(P>0.05)$. Concentrations of $20: 5 n-3$ and 22:6n-3 were significantly higher in sea cucumber fed the SLO diet than in those fed on the other diets. The highest 18:2n-6 and 18:3n-3 contents were observed in sea cucumber fed the SO and LO diets, respectively. The results of this study suggest that squid liver oil could be used as a good lipid source in formulated diets for juvenile sea cucumber.
\end{abstract}

Key words: Apostichopus japonicus, Sea cucumber, Lipid source, Growth, Fatty acid composition

\section{Introduction}

Lipid is an important nutrient, providing energy, essential fatty acids (EFA), and fat-soluble nutrients for the normal growth of fish. Providing adequate amounts of EFA is necessary for the normal growth and survival of animals, especially during juvenile stages (Sargent et al., 1999), because it plays important roles in the fluidity, permeability, and enzyme activity of membrane (Stubbs and Smith, 1984). The EFA requirements of aquatic animals are largely affected by species, water temperature, and salinity, and are different from those of terrestrial animals (Castell, 1979; Cowey and Sargent, 1979).

The sea cucumber Apostichopus japonicus is an important fishery resource in Korea, China, and Japan (Sloan, 1984). Market demand for the species has increased with increasing awareness of sea cucumber as a healthy food for humans. However, supplies of sea cucumber obtained from the wild have declined

\footnotetext{
*Corresponding author: smlee@gwnu.ac.kr due to over-exploitation and pollution (Conand, 2004;
}

Uthicke, 2004). Therefore, it is necessary to increase production and population of the species through aquaculture. Recently, several studies have examined the sea cucumber's requirements for nutrients such as proteins, lipids, carbohydrates, and ascorbic acid (Okorie et al., 2008; Seo et al., 2008; Choi et al., 2009). Feed ingredient studies (Yuan et al., 2006; Liu et al., 2009) have also been carried out to develop a practical diet for efficient sea cucumber culture. However, no information concerning the influence of dietary EFA source on sea cucumber is available. Thus, this study was conducted to evaluate the effects of dietary lipid sources on the growth and fatty acid composition of juvenile sea cucumber.

\section{Materials and Methods}

\section{Diet preparation}

Fatty acid composition of the lipid sources used in the experimental diets is shown in Table 1. Table 1. Fatty acid composition ( $\%$ of total fatty acids) of the dietary lipid sources 


\begin{tabular}{lccc}
\hline \multirow{2}{*}{ Fatty acids } & \multicolumn{3}{c}{ Dietary lipid sources } \\
\cline { 2 - 4 } & Soybean oil & Linseed oil & Squid liver oil \\
\hline C14:0 & & & 6.4 \\
C15:0 & & & 0.6 \\
C15:1 & & 5.2 & 0.2 \\
C16:0 & 11.4 & & 22.3 \\
C16:1 & & & 0.2 \\
C17:0 & & 23.0 & 0.5 \\
C18:0 & 30.3 & 17.6 & 1.0 \\
C18:1n-9 & 51.4 & 54.1 & 31.6 \\
C18:2n-6 & 0.8 & 0.2 & 0.3 \\
C18:3n-3 & & & 1.8 \\
C18:3n-6 & 0.4 & & 0.2 \\
C20:0 & 0.5 & & 0.4 \\
C20:1 & & 0.1 \\
C20:2 & & & 2.0 \\
C20:3n-3 & & & 3.5 \\
C20:3n-6 & & & 0.2 \\
C20:4n-6 & & & 0.3 \\
C20:5n-3 & & & 14.3 \\
C21:0 & 5.1 & & 0.1 \\
C22:1 & & & 0.4 \\
C22:2 & & & 1.1 \\
C22:6n-3 & & & 0.8 \\
C23:0 & & & 29.7 \\
n-3HUFA & & & \\
\hline
\end{tabular}

${ }^{1}$ Highly unsaturated fatty acid $(\mathrm{C} \geq 20)$.

Three diets containing $2 \%$ squid liver oil (SLO), soybean oil (SO), or linseed oil (LO) and a control diet $(\mathrm{CON})$ without added lipids were prepared (Table 2). Soybean meal and wheat flour were used as the main protein and carbohydrate sources, respectively. The experimental diets were formulated using a moist pellet machine, and were ground to a powder (180 mesh) after being dried overnight at $60^{\circ} \mathrm{C}$. All diets were stored at $-30^{\circ} \mathrm{C}$ until use. The fatty acid composition of the experimental diets is shown in Table 3.

\section{Experimental animals and feeding trials}

Juvenile sea cucumber (Apostichopus japonicus) were purchased from a local sea cucumber farm (Goseong, Korea). They were acclimated to experimental conditions for 2 weeks before the feeding trial commenced. Sea cucumber (average weight, 1.4 $0.02 \mathrm{~g}$ ) were randomly distributed into $50 \mathrm{~L}$ rectangular plastic tanks, each containing $40 \mathrm{~L}$ of water, at a density of 50 sea cucumber per tank. Three replicate groups of sea cucumber were fed one of the four experimental diets at a rate of $5 \%$ of sea cucumber body weight once a day $(17: 00 \mathrm{~h})$ for 12 weeks. Filtered seawater was supplied at a flow rate of $1 \mathrm{~L} / \mathrm{min}$, and aeration was provided continuously Table 2. Ingredients and proximate composition (\%) of the experimental diets

\begin{tabular}{|c|c|c|c|c|}
\hline & \multicolumn{4}{|c|}{ Diets } \\
\hline & $\mathrm{CON}$ & SO & LO & SLO \\
\hline \multicolumn{5}{|l|}{ Ingredients (\%) } \\
\hline Soybean meal & 40.0 & 40.0 & 40.0 & 40.0 \\
\hline Wheat flour & 44.8 & 42.8 & 42.8 & 42.8 \\
\hline Soybean oil & & 2.0 & & \\
\hline Linseed oil $^{1}$ & & & 2.0 & \\
\hline Squid liver oil ${ }^{2}$ & & & & 2.0 \\
\hline Sargassum thunbergii & 10.0 & 10.0 & 10.0 & 10.0 \\
\hline Vitamin premix ${ }^{3}$ & 2.0 & 2.0 & 2.0 & 2.0 \\
\hline Mineral premix & 3.0 & 3.0 & 3.0 & 3.0 \\
\hline Choline salt $(50 \%)$ & 0.2 & 0.2 & 0.2 & 0.2 \\
\hline \multicolumn{5}{|c|}{ Proximate composition (\%, dry matter basis) } \\
\hline Crude protein & 31.0 & 29.6 & 30.1 & 30.1 \\
\hline Crude lipid & 1.6 & 3.8 & 3.6 & 3.6 \\
\hline Ash & 9.1 & 9.6 & 9.6 & 9.1 \\
\hline Crude fiber & 4.0 & 4.2 & 4.1 & 3.4 \\
\hline $\mathrm{N}$-free extract ${ }^{5}$ & 54.3 & 52.8 & 52.7 & 53.8 \\
\hline Gross energy (kcal/ g diet) & 4.2 & 4.3 & 4.3 & 4.3 \\
\hline
\end{tabular}

${ }^{1,2}$ Provided by E-wha Oil \& Fat Ind. Co., Busan, Korea.

${ }^{3}$ Vitamin premix, contained the following amount which were diluted in cellulose $(\mathrm{g} / \mathrm{kg}$ mix): $\mathrm{L}$ ascorbic acid, 200; DL- $\alpha$-tocopheryl acetate, 20; thiamin hydrochloride, 5; riboflavin, 8; pyridoxine hydrochloride, 2; niacin, 40; Ca-D-pantothenate, 12; myo-inositol, 200; D-biotin, 0.4; folic acid, 1.5; paminobenzoic acid, 20; menadione, 4; retinyl acetate, 1.5; chloecalciferol, 0.003; cyanocobalamin, 0.003 .

${ }^{4}$ Mineral premix, contained the following ingredients (g/kg mix): $\mathrm{NaCl}, 7 ; \mathrm{MgSO}_{4} \cdot 7 \mathrm{H}_{2} \mathrm{O}, 105 ; \mathrm{NaH}_{2} \mathrm{PO}_{4}$. $2 \mathrm{H}_{2} \mathrm{O}, 175 ; \mathrm{KH}_{2} \mathrm{PO}_{4}, 224 ; \mathrm{CaH}_{4}\left(\mathrm{PO}_{4}\right)_{2} \cdot \mathrm{H}_{2} \mathrm{O}, 140$; Ferric citrate, 17.5; Ca-lactate, $21.8 ; \mathrm{ZnSO}_{4} \cdot 7 \mathrm{H}_{2} \mathrm{O}$, 2.8; $\mathrm{CuCl}, 0.2 ; \mathrm{AlCl}_{3} \cdot 6 \mathrm{H}_{2} \mathrm{O}, 0.11 ; \mathrm{KIO}_{3}, 0.02$; $\mathrm{Na}_{2} \mathrm{Se}_{2} \mathrm{O}_{3}, 0.007 ; \mathrm{MnSO}_{4} \cdot \mathrm{H}_{2} \mathrm{O}, 1.4 ; \mathrm{CoCl}_{2} \cdot 6 \mathrm{H}_{2} \mathrm{O}$, 0.07 .

${ }^{5}$ Calculated by difference $(100$-crude protein + crude lipid + ash + crude fiber).

into each tank. Water temperature was maintained at $14.7 \pm 1.2^{\circ} \mathrm{C} \quad($ mean $\pm \mathrm{SD})$, and the photoperiod followed natural conditions during the feeding trial. Each tank was cleaned by siphoning every two days.

\section{Sample collection and chemical analysis}

One hundred sea cucumber at the beginning and all surviving sea cucumber at the end of the feeding trial were sampled and stored at $-75^{\circ} \mathrm{C}$ for chemical analysis. The proximate composition of the sea cucumber was determined using standard methods (AOAC, 1990). Crude protein $(\mathrm{N} \times 6.25)$ was determined by the Kjeldahl method using an Auto Kjeldahl system (Buchi, Flawil, Switzerland). Crude lipid was determined by the ether-extraction method. Table 3. Fatty acid composition ( $\%$ of total fatty acids) of the experimental diets 


\begin{tabular}{lrrrr}
\hline \multirow{2}{*}{ Fatty acid } & \multicolumn{4}{c}{ Diets } \\
\cline { 2 - 5 } & CON & \multicolumn{1}{c}{ SO } & \multicolumn{1}{c}{ LO } & SLO \\
\hline C14:0 & 0.9 & 0.6 & 0.3 & 4.8 \\
C16:0 & 60.1 & 42.9 & 22.4 & 41.0 \\
C16:1 & 0.4 & 0.2 & 0.5 & 2.4 \\
C18:0 & 8.9 & 9.0 & 5.6 & 6.9 \\
C18:1n-9 & 9.8 & 19.1 & 19.4 & 19.7 \\
C18:2n-6 & 10.1 & 18.5 & 30.9 & 14.7 \\
C18:3n-3 & 0.7 & 1.3 & 16.8 & 1.2 \\
C20:1 & 4.8 & 3.0 & 1.3 & 1.9 \\
C20:2 & 0.7 & 1.4 & 0.7 & 1.3 \\
C20:4n-6 & 1.2 & 1.5 & 0.3 & 1.1 \\
C20:5n-3 & 0.0 & 0.0 & 0.0 & 1.7 \\
C22:0 & 1.1 & 0.9 & 0.4 & 0.5 \\
C22:2 & 1.5 & 1.4 & 1.4 & 1.0 \\
C22:6n-3 & 0.0 & 0.0 & 0.0 & 1.8 \\
n-3 HUFA & 0.0 & 0.0 & 0.0 & 3.5 \\
\hline
\end{tabular}

${ }^{1}$ Highly unsaturated fatty acid $(\mathrm{C} \geq 20)$.

Moisture was determined by oven drying at $105^{\circ} \mathrm{C}$ for 6 hours. Crude fiber was determined using an automatic fiber analyzer (Velp Fiwe6, Milano, Italy) and ash was determined using a furnace muffler at $600^{\circ} \mathrm{C}$ for 4 hours. The nitrogen-free extract (NFE) was calculated from the difference. Gross energy was analyzed using an adiabatic bomb calorimeter (Parr 1356, Moline, IL, USA). Lipids for fatty acid analysis were extracted by the method of Folch et al. (1957), and fatty acid methylesters were prepared by transesterification with $14 \% \mathrm{BF}_{3}-\mathrm{MeOH}$ (Sigma, St Louis, MO, USA). Fatty acid methyl esters were separated and quantified using a gas chromatograph (HP6890 N, Hewlett-Packard, Palo Alto, CA, USA) with a flame ionization detector, equipped with a $\mathrm{SP}^{\mathrm{TM}}-2560$ capillary column $(100 \mathrm{~m} \times 0.25 \mathrm{~mm}$ i.d., film thickness $0.20 \mu \mathrm{m}$, Supelco, Bellefonte, PA, USA). Injector and detector temperatures were maintained at $260^{\circ} \mathrm{C}$. The column temperature was programmed from $140^{\circ} \mathrm{C}$ to $240^{\circ} \mathrm{C}$ at a rate of $4^{\circ} \mathrm{C} \mathrm{min}{ }^{-1}$. Helium was used as the carrier gas. Fatty acids were identified by comparison with the retention times of standard fatty acid methyl esters (PUFA 37 component FAME Mix, Supelco).

\section{Statistical analysis}

Data were subjected to one-way ANOVA to test the effects of dietary lipid source. When significant $(P<0.05)$ differences were detected, Duncan's multiple range test was used to rank the groups. The data are presented as mean $\pm \mathrm{SE}$ of the three replicate groups. All statistical analyses were carried out using SPSS version 12.0 (SPSS, Chicago, IL, USA).

\section{Results and Discussion}

The growth performance of juvenile sea cucumber fed for 12 weeks on the experimental diets containing various lipid sources is shown in Table 4. Sea cucumber survival ranged from $74 \%$ to $83 \%$ with no significant differences among dietary treatments $(P>$ $0.05)$. The weight gain of sea cucumber was significantly affected by dietary lipid source $(P<$ $0.05)$. The highest weight gain was observed in sea cucumber fed the SLO diet, whereas the weight gain of sea cucumber fed the SO diet was the lowest $(P<$ $0.05)$. The growth results indicate that juvenile sea cucumber requires n-3 highly unsaturated fatty acids (n-3 HUFA) such as 20:5n-3 and 22:6n-3 for normal growth. Interestingly, sea cucumber fed the SO and LO diets exhibited lower weight gain than did those fed the CON diet without added lipids. This was thought to be associated with the low availability of plant lipids to sea cucumber and may indicate that it is not necessary to add $18: 2 n-6$ and $18: 3 n-3$ to sea cucumber feed.

Several studies have reported that dietary n-3 HUFA is essential for the normal growth of invertebrates (Lee et al., 2002) and marine fish species such as the flounder Paralichthys olivaceus (Kim et al., 2002). Type and level of essential fatty acids required for normal growth differ among fish species. Whereas freshwater species require 18:2n-6 and/or 18:3n-3 (Castell et al., 1972a, b; Kanazawa et al., 1980; Takeuchi, 1996), marine species generally require n-3 HUFA such as 20:5n-3 and 22:6n-3 for normal growth and development (Van Ballaer et al., 1985; Izquierdo et al., 1989; Kim et al., 2002). Because marine oils, such as the squid liver oil, which was found to increase growth rates in this study, contain a high proportion of n-3 HUFA and an adequate 20:5n-3/22:6n-3 ratio (Kalogero-poulos et al., 1992), this could be used as a good dietary lipid source to satisfy the 20:5n-3 and 22:6n-3 requirements of juvenile sea cucumber.

Weight gains recorded in this study were lower than those reported from other nutritional studies concerning sea cucumber (Yang et al., 2005; Dong et al., 2006; Zhou et al., 2006; An et al., 2007; Okorie et al., 2008). This may be related to the presence of antinutritional factors and/or deficiency in essential amino acid such as methionine in dietary soybean meal (Rumsey et al., 1994; Anderson and Wolf, 1995). In addition, remarkable size variations among individuals in each tank were observed after the feeding trial. This phenomenon may be another possible reason for the low mean growth rate of the

Table 4. Growth performance and survival of juvenile sea cucumber fed the diets containing different lipid 
sources for 12 weeks $^{1}$

\begin{tabular}{lcccc}
\hline & \multicolumn{3}{c}{ Diets } \\
\cline { 2 - 5 } & CON & SO & LO & SLO \\
\hline Initial mean weight (g/ sea cucumber) & $1.4 \pm 0.01$ & $1.4 \pm 0.01$ & $1.4 \pm 0.01$ & $1.4 \pm 0.01$ \\
Survival (\%) & $74 \pm 5.0$ & $77 \pm 1.8$ & $83 \pm 1.8$ & $81 \pm 2.4$ \\
Weight gain (\%) & $23.6 \pm 6.5^{\mathrm{b}}$ & $3.8 \pm 1.4^{\mathrm{a}}$ & $14.1 \pm 1.1^{\text {ab }}$ & $45.2 \pm 5.0^{\mathrm{c}}$ \\
\hline
\end{tabular}

${ }^{1}$ Values (mean \pm SE of triplicate groups) in each row with different superscripts are significantly different $(P<$ $0.05)$.

${ }^{2}$ Weight gain $(\%)=($ final body weight - initial body weight $) \times 100 /$ initial body weight.

Table 5. Proximate compositions (\%) of whole body in sea cucumber fed the diets containing different lipid sources for 12 weeks

\begin{tabular}{lrrrrr}
\hline & Initial & \multicolumn{3}{c}{ Diets } \\
\cline { 3 - 6 } & & \multicolumn{1}{c}{ CON } & \multicolumn{1}{c}{ SO } & \multicolumn{1}{c}{ LO } & SLO \\
\hline Moisture & 92.3 & $90.7 \pm 0.28$ & $90.1 \pm 0.19$ & $91.0 \pm 0.75$ & $91.1 \pm 0.14$ \\
Crude protein & 3.1 & $4.0 \pm 0.18$ & $3.8 \pm 0.14$ & $3.7 \pm 0.07$ & $3.7 \pm 0.06$ \\
Crude lipid & 0.3 & $0.6 \pm 0.50$ & $0.2 \pm 0.13$ & $0.4 \pm 0.03$ & $0.2 \pm 0.10$ \\
Ash & 3.6 & $3.5 \pm 0.12$ & $3.5 \pm 0.03$ & $3.5 \pm 0.03$ & $3.4 \pm 0.04$ \\
\hline
\end{tabular}

Table 6. Fatty acid composition (\% of total fatty acids) of whole body in sea cucumber fed the diets containing different lipid sources for 12 weeks ${ }^{1}$

\begin{tabular}{lccccc}
\hline \multirow{2}{*}{ Fatty acids } & Initial & \multicolumn{3}{c}{ Diets } \\
\cline { 3 - 6 } & & CON & SO & LO & SLO \\
\hline C14:0 & 1.1 & $1.3 \pm 0.02^{\mathrm{b}}$ & $1.0 \pm 0.03^{\mathrm{a}}$ & $1.0 \pm 0.03^{\mathrm{a}}$ & $1.0 \pm 0.06^{\mathrm{a}}$ \\
C14:1 & 0.3 & $0.3 \pm 0.14$ & $0.2 \pm 0.02$ & $0.2 \pm 0.02$ & $0.2 \pm 0.12$ \\
C16:0 & 4.5 & $5.2 \pm 0.35^{\mathrm{c}}$ & $3.3 \pm 0.05^{\mathrm{a}}$ & $3.7 \pm 0.21^{\mathrm{ab}}$ & $4.8 \pm 0.57^{\mathrm{bc}}$ \\
C16:1 & 3.0 & $3.0 \pm 0.19^{\mathrm{b}}$ & $2.6 \pm 0.19^{\mathrm{a}}$ & $3.2 \pm 0.05^{\mathrm{bc}}$ & $3.6 \pm 0.05^{\mathrm{c}}$ \\
C18:0 & 5.5 & $4.1 \pm 0.20^{\mathrm{b}}$ & $3.5 \pm 0.06^{\mathrm{a}}$ & $3.6 \pm 0.04^{\mathrm{a}}$ & $4.4 \pm 0.09^{\mathrm{b}}$ \\
C18:1n-9 & 16.2 & $14.5 \pm 0.22^{\mathrm{a}}$ & $15.7 \pm 0.26^{\mathrm{b}}$ & $16.6 \pm 0.35^{\mathrm{b}}$ & $20.2 \pm 0.36^{\mathrm{c}}$ \\
C18:2n-6 & 7.3 & $28.8 \pm 0.98^{\mathrm{c}}$ & $30.2 \pm 0.52^{\mathrm{c}}$ & $25.5 \pm 0.62^{\mathrm{b}}$ & $22.2 \pm 0.23^{\mathrm{a}}$ \\
C18:3n-3 & - & $1.1 \pm 0.08^{\mathrm{a}}$ & $1.3 \pm 0.05^{\mathrm{a}}$ & $6.0 \pm 0.66^{\mathrm{b}}$ & $0.7 \pm 0.35^{\mathrm{a}}$ \\
C20:0 & 11.2 & $9.9 \pm 0.49$ & $9.7 \pm 0.35$ & $9.2 \pm 0.54$ & $9.4 \pm 0.15$ \\
C20:2 & 3.8 & $9.6 \pm 0.27^{\mathrm{c}}$ & $9.4 \pm 0.15^{\mathrm{c}}$ & $8.4 \pm 0.33^{\mathrm{b}}$ & $7.6 \pm 0.14^{\mathrm{a}}$ \\
C20:4n-6 & 24.2 & $15.9 \pm 1.14^{\mathrm{b}}$ & $14.4 \pm 0.81^{\mathrm{b}}$ & $13.7 \pm 0.23^{\mathrm{b}}$ & $9.9 \pm 0.43^{\mathrm{a}}$ \\
C20:5n-3 & 15.4 & $6.5 \pm 0.09^{\mathrm{a}}$ & $7.0 \pm 0.36^{\mathrm{a}}$ & $6.8 \pm 0.09^{\mathrm{a}}$ & $11.6 \pm 0.19^{\mathrm{b}}$ \\
C22:6n-3 & 7.4 & $2.8 \pm 0.91^{\mathrm{a}}$ & $1.8 \pm 0.21^{\mathrm{a}}$ & $2.1 \pm 0.51^{\mathrm{a}}$ & $4.5 \pm 0.02^{\mathrm{b}}$ \\
n-3 HUFA & 22.9 & $9.3 \pm 0.98^{\mathrm{a}}$ & $8.7 \pm 0.15^{\mathrm{a}}$ & $8.9 \pm 0.44^{\mathrm{a}}$ & $16.1 \pm 0.17^{\mathrm{b}}$ \\
\hline
\end{tabular}

${ }^{\mathrm{T}}$ Values (mean \pm SE of triplicate groups) in each row with different superscripts are significantly different $(P<$ $0.05)$.

${ }^{2}$ Highly unsaturated fatty acid $(C \geq 20)$.

sea cucumber. Similar phenomena have been observed in sea cucumber aquaculture facilities and in our previous studies (Seo et al., 2008; 2009). Although the exact reasons for the observed size variations are not known, they are thought to be related to natural characteristics of the sea cucumber, variations in environmental conditions, etc.

Proximate and fatty acid compositions of the sea cucumber whole body are presented in Tables 5 and 6 , respectively. No significant differences were observed in the contents of moisture, crude protein, crude lipid, and ash $(P>0.05)$. It is well established that the fatty acid composition of animals reflects the fatty acid composition of their dietary lipid sources (Bell et al., 1994; Sargent et al., 1995; Lee et al., 2002; Seo et al., 2008). In the present study, 18:1n-9, 18:2n-6, and 20:4n-6 were found to be abundant fatty acids in sea cucumber, and the highest 18:2n-6, 18:3n-3, and n-3 HUFA contents were observed in juvenile sea cucumber that were fed the SO, LO, and SLO diets, respectively. In addition, the 18:1n-9 contents of sea cucumber fed the SO, LO, and SLO diets, the 18:3n-3 contents of those fed the LO treatment, and the n-3 HUFA contents of those fed the SLO treatment were significantly higher than those of sea cucumber fed the control diet $(P<0.05)$. 
These findings indicate that fatty acid com-positions of sea cucumber varied with variations in fatty acid compositions of their dietary lipid sources, which is in accordance with previous studies of sea cucumber (Seo et al., 2008), snail (Lee et al., 2002), and flounder (Kim et al., 2002). The lower n-3 HUFA contents of sea cucumber fed on the LO diet compared with the SLO diet may be due to the very limited capacity of sea cucumber to convert $18: 3 n-3$ to $20: 5 n-3$ or $22: 6 n-3$. Similar findings were reported for marine fish such as turbot (Owen et al., 1975). Although, all diets had low $20: 4 n-6$ levels $(0.3 \%$ to $1.5 \%)$, the relatively high $20: 4 n-6$ levels $(9.9 \%$ to $15.9 \%$ ) in sea cucumber at the end of the feeding trial indicate that sea cucumber may have the capacity to elongate or desaturate 20:4n-6 from shorter polyunsaturated fatty acids.

Based on the results of this study, it is concluded that squid liver oil could be used as a good source of lipid in formulated diets for juvenile sea cucumber.

\section{Acknowledgments}

This work was supported by the funds of the Ministry for Food, Agriculture, Forestry and Fisheries in Korea.

\section{References}

An ZH, Dong YW and Dong SL. 2007. Temperature effects on growth-ration relationships of juvenile sea cucumber Apostichopus japonicus (Selenka). Aquaculture 272, 644-648.

Anderson RL and Wolf WR. 1995. Compositional changes in trypsin inhibitors, phytic acid, saponins and isoflavones related to soybean processing. J Nutr 125, 581-588.

AOAC (Association of Official Analytical Chemists). 1990. Official Methods of Analysis. 15th ed. Association of Official Analytical Chemists, Arlingon, Virginia, 1298.

Bell JG, Tocher DR, McDonald FM and Sargent JR. 1994. Effects of diets rich in linoleic (18:2n-6) and $\alpha$-linolenic (18:3n-3) acids on the growth, lipid class and fatty acid compositions and eicosanoid pro-duction in juvenile turbot (Scophthalmus maximus). Fish Physiol Biochem 13, 105-118.

Castell JD, Sinnhuber RO, Lee DJ and Wales JH. 1972a. Essential fatty acids in the diet of rainbow trout (Salmo gairdneri): physiological symptoms of EFA deficiency. J Nutr 102, 87-92.

Castell JD, Sinnhuber RO, Wales JH and Lee DJ. 1972b. Essential fatty acids in the diet of rainbow trout (Salmo gairdneri): growth, feed conversion and some gross deficiency symptoms. J Nutr 102, 77-86.

Castell JD. 1979. Review of lipid requirements of finfish. In: Proceeding of the World Symposium on Finfish Nutrition and Fishfeed Technology. Halver J and Tiews C, eds. Hamburg, Germany, 59-84.

Choi J, Seo JY and Lee SM. 2009. Effects of sources and levels of dietary carbohydrate on growth and body composition of juvenile sea cucumber, Apostichopus japonicus. Kor Soc Fish Aquat Sci 12, 203-208.

Conand C. 2004. Present status of world sea cucumber resources and utilization: an international overview. In: Advances in Sea Cucumber Aquaculture and Management. Lovatelli A, Conand C, Purcell S, Uthicke S, Hamel JF and Mercier A, eds. FAO, Rome, Italy, 13-23.

Cowey CB and Sargent JR. 1979. Nutrition. In: Fish Physiology. Hoar WS, Randall DJ and Brett JR, eds. Academic Press, Orlando, F.L., 1-69.

Dong YW, Dong SL, Tian XL, Wang F and Zhang MZ. 2006. Effects of diel temperature fluctuations on growth, oxygen consumption and proximate body composition in the sea cucumber Apostichopus japonicus Selenka. Aquaculture 255, 514-521.

Folch J, Lees M and Stanley GHS. 1957. A simple method for the isolation and purification of total lipids from animal tissues. J Biol Chem 226, 469-509.

Izquierdo MS, Watanabe T, Takeuchi T, Arakawa T and Kitajima C. 1989. Optimal EFA levels in Artemia to meet the EFA requirements of red seabream (Pagrus major). In: The Current Status of Fish Nutrition in Aquaculture. Takeda $\mathrm{M}$ and Watanabe T, eds. Japan Translation Centre, Tokyo, Japan, 221-232.

Kalogeropoulos N, Alexis MN and Henderson RJ. 1992. Effect of dietary soybean and cod-liver oil levels on growth and body composition of gilthead bream (Sparus aurata). Aquaculture 104, 293-308.

Kanazawa A, Teshima SI, Sakamoto M and Awal Md. A. 1980. Requirements of Tilapia zillii for essential fatty acids. Bull Jap Soc Sci Fish 46, 1353-1356.

Kim KD, Lee SM, Park HG, Bai SC and Lee YH. 2002. Essentiality of dietary n-3 highly unsaturated fatty acids in juvenile Japanese flounder (Paralichthys olivaceus). J World Aquacult Soc 33, 432-440.

Lee SM, Kim KD, Lim TJ and Bang IC. 2002. Effects of dietary lipid sources on growth and body composition of snail (Semisulcospira gottschei). J Fish Sci Tech 5, 165-171.

Liu Y, Dong S, Tian X, Wang F and Gao Q. 2009. Effects of dietary sea mud and yellow soil on growth and energy budget of the sea cucumber Apostichopus japonicus (Selenka). Aquaculture 286, 266-270.

Okorie EO, Ko SH, Go SG, Lee SH, Bae JY, Han KM and Bai SC. 2008. Preliminary study of the optimum dietary 
ascorbic acid level in sea cucumber, Apostichopus japonicus (Selenka). J World Aquacult Soc 39, 758-765.

Owen JM, Adron JW, Middleton C and Cowey CB. 1975. Elongation and desaturation of dietary fatty acids in turbot Scophthalmus maximus L. and rainbow trout Salmo gairdnerii Rich. Lipids 10, 528-531.

Rumsey GL, Siwichi AK, Anderson DP and Bowser PR. 1994. Effect of soybean protein on serological response, non-specific defense mechanisms, growth, and protein utilization in rainbow trout. Vet Immunol Immunopathol 41, 323-339.

Sargent JR, Bell JG, Bell MV, Henderson RJ and Tocher DR. 1995. Requirement criteria for essential fatty acids. J Appl Ichthyol 11, 183-198.

Sargent JR, Bell JG, McEvoy LA, Tocher D and Estevez A. 1999. Recent developments in the essential fatty acid nutrition of fish. Aquaculture 177, 191-199.

Seo JY, Choi J, Kim GU, Cho SS, Park HG and Lee SM. 2008. Effects of dietary protein and lipid levels on growth and body composition of juvenile sea cucumber Stichopus japonicus. J Aquacult 21, 19-25.

Seo JY, Kim DG, Kim GU, Cho SS, Park HG and Lee SM. 2009. Effect of different substrates in the rearing tank on growth and body composition of juvenile sea cucumber Apostichopus japonicus. J Aquacult 22, 118121.

Sloan NA. 1984. Echinorderm fisheries of the world: a review. In: Echinodermata (Proceedings of the Fifth International Echinoderm Conference). Balkema AA. ed. Rotterdam, Netherlands, 109-124.

Stubbs CD and Smith AD. 1984. The modification of mammalian membrane polyunsaturated fatty acid composition on relation to membrane fluidity and function. Biochim Biophys Acta 779, 89-137.
Takeuchi T. 1996. Essential fatty acid requirements in carp. Arch Anim Nutr 49, 23-32.

Uthicke C. 2004. Overfishing of holothurians: lessons from the Great Barrier Reef. In: Advances in Sea Cucumber Aquaculture and Management. Lovatelli A, Conand C, Purcell S, Uthicke S, Hamel JF and Mercier A, eds. FAO, Rome, Italy, 163-171.

Van Ballaer E, Amat F, Hontoria F, Leger P, and Sorgeloos P. 1985. International study on Artemia: XXXIV. Preliminary results on the nutritional evaluation of $\omega 3$ - HUFA enriched Artemia nauplii for the larvae of the sea bass Dicentrarchus labrax. Aquaculture 49, 223-229.

Yang HX, Yuan X, Zhou Y, Mao Y, Zhang T and Liu Y. 2005. Effects of body size and water temperature on food consumption and growth in the sea cucumber Apostichopus japonicus (Selenka) with special reference to aestivation, Aquacult Res 36, 1085-1092.

Yuan X, Yang H, Zhou Y, Mao Y, Zhang T and Liu Y. 2006. The influence of diets containing dried bivalve feces and/or powdered algae on growth and energy distribution in sea cucumber Apostichopus japonicus (Selenka) (Echinodermata: Holothuroidea). Aquaculture 256, 457-467.

Zhou Y, Yang H, Liu S, Yuan X, Mao Y, Liu Y, Xu X and Zhang F. 2006. Feeding and growth on bivalve biodeposits by the deposit feeder Stichopus japonicus Selenka (Echinodermata: Holothuroidea) co-cultured in lantern nets. Aquaculture 256, 510-520.

(Received 4 March 2010; Revised 12 May 2010; Accepted 27 May 2010) 